\title{
Some aspects of regulation of luteal function and luteoly- sis in equine corpora lutea
}

\author{
Graça Ferreira-Dias ${ }^{1}$ and Dariusz J. Skarzynski² \\ C.I.I.S.A., Faculty of Veterinary Medicine, TU Lisbon, Lisbon, Portugal ${ }^{1}$ and Institute of Animal Reproduction and Food Research, Olsztyn, Poland ${ }^{2}$
}

\begin{abstract}
Summary
Like in other mammalian species, in the mare, in every ovarian cycle, a complex process of luteinization leads to corpus luteum (CL) formation. The $\mathrm{CL}$ produces progesterone (P4), a required hormone for establishment and maintenance of early pregnancy. Luteal angiogenesis in the mare, necessary for the CL formation, is followed by vascular regression during tissue involution, coordinated with the development and regression of non-vascular tissue (steroidogenic cells included). These processes might be regulated by several factors, still not completely understood. This work reviews some of our studies on this field in the mare. In the equine $\mathrm{CL}$, tumour necrosis factor (TNF $\alpha$ ) and nitric oxide (NO) may stimulate the production of angiogenic factor(s) and prostaglandin (PG) E2, necessary for vascular and non-vascular development during the early luteal phase. Increased microvascularization is accompanied by the synthesis of P4, rise in P4 receptor number and an increase in the number of large luteal cells. This suggests the importance of large luteal cells in the auto/paracrine regulation of P4 synthesis in the equine $\mathrm{CL}$. However, when angiogenesis is complete, long term exposure to progestagens appears to inhibit the proliferative/angiogenic activity. PGF2 $\alpha$ may also induce luteal (including vascular) regression of the equine CL. Moreover, NO and P4 dependent process of inhibition of angiogenic factor(s) production might be preparing the $\mathrm{CL}$ for functional and structural regression. Oppositely to the early luteal phase, during late luteal phase $\mathrm{NO}$ and cytokines may induce several processes leading to the regression of equine $\mathrm{CL}$. Besides, caspase-3, the effector enzyme of apoptosis, might also play an important role during luteal tissue involution. Nevertheless, further studies are needed to elucidate the mechanisms and the relationship between the dichotomy of loss of function and/or luteal involution in the mare.
\end{abstract}

Keywords: Corpus luteum, mare, angiogenesis, cytokines, Caspase-3, reproduction

\section{Einige Aspekte bezüglich der Regulation der lutealen Funktion und Luteolyse in equinen Corpora lutea}

Im equinen Ovar können, wie bei anderen Säugetieren, innerhalb jedes Zyklus Luteinisierungsvorgänge mit Ausbildung eines Corpus luteum (CL) beobachtet werden, welches das für die Herstellung und Erhaltung der frühen Trächtigkeit essentielle Hormon Progesteron (P4) synthetisiert. Die luteale Angiogenese im Rahmen der Gelbkörperentwicklung sowie die darauf folgende Gefäßregression zum Zeitpunkt der Gewebeinvolution verlaufen parallel mit der Entwicklung und der Regression des nichtvaskulären Gewebes (inklusive der steroidhormonbildenden Zellen). Diese, vermutlich durch zahlreiche Faktoren regulierte Abläufe sind bis zum heutigen Zeitpunkt nicht vollständig geklärt. Die vorliegende Arbeit liefert einen Überblick über eigene Studien bei Stuten hinsichtlich dieser Thematik. Im equinen CL wird die Produktion von angiogenen Faktoren und Prostaglandin (PG) E2, welche für die vaskuläre und nichtvaskuläre Entwicklung während der Gelbkörperanbildung von Bedeutung sind, möglicherweise durch den Tumor Nekrose Faktor $\alpha$ (TNF $\alpha$ ) und Stickoxid (NO) stimuliert. Die ansteigende Mikrovaskularisierung verläuft parallel zu der Synthese von P4, einer Zunahme der Anzahl P4-Rezeptoren sowie großer Luteinzellen. Diese Befunde lassen vermuten, dass die großen Luteinzellen für die autokrine/parakrine Regulation der P4-Synthese im equinen CL von Bedeutung sind. Nach Abschluss der Angiogenese im Gelbkörper scheint eine Langzeiteinwirkung von Progestagenen die proliferative/angiogene Aktivität zu hemmen. PGF2 $\alpha$ induziert vermutlich die luteale (und vaskuläre) Regression im equinen CL. Darüber hinaus bereitet möglicherweise eine NO- und P4-abhängige Inhibition der Produktion angiogener Faktoren den Gelbkörper auf die funktionelle und strukturelle Regression vor. Im Gegensatz zur frühen Lutealphase induzieren NO und Zytokine in der späten Lutealphase eventuell einige Abläufe, die zur Regression des equinen CL führen. Zusätzlich könnte auch die Caspase-3, das Effektor-Enzym der Apoptose, eine bedeutende Rolle während der lutealen Regression spielen. Dennoch sind weiterführende Studien nötig, um die Mechanismen und die Zusammenhänge der Dichotomie des lutealen Funktionsverlusts und/oder der lutealen Involution bei der Stute zu verstehen.

Schlüsselwörter: Corpus luteum, Stute, Angiogenese, Zytokine, Caspase-3, Reproduktion

\section{Introduction}

In the mare, like in other mammalian species, soon after ovulation, a complex process of luteinization leads to corpus luteum $(\mathrm{CL})$ formation in response to luteotropins. The $\mathrm{CL}$ is a transient endocrine gland that evolves from the luteinization of the remnants of the ovulated follicle, namely the theca and the granulosa cells (Ginther 1992). The luteinizing process is necessary for the production of progesterone (P4) (Murphy 2000). The physiologic mechanisms that regulate luteal function in the mare are rather complex and not very well under- stood. Maternal functions of the ovarian luteal structure can be ascribed to its importance on the synthesis of P4 that enables the establishment and maintenance of early gestation in this species.

\section{Formation of the corpus luteum}

It is rather documented that the luteinizing hormone $(\mathrm{LH})$ and prostaglandin (PG) E2 are the main luteotrophic hormones (Juengel and Niswender 1999, Skarzynski et al. 2001) (Fig 1.). 
Luteal tissue formation is characterized by the differentiation and growth of large and small luteal cells (Roberto da Costa et al. 2005), and proliferation of non luteal cells such as immune cells and fibroblasts (Lei et al. 1991, Broadley et al. 1994, Lawler et al. 1999). In each ovarian cycle, besides cellular proliferation and remodelling of extracellular matrix (Goldberg et al. 1996, Curry and Osteen 2001), changes in luteal vascularity take place (Tamanini and De Ambrogi 2004).

In most species, luteal steroid producing cells are small luteal cells or large luteal cells, which can be distinguished on the basis of morphological and biochemical criteria (van Niekerk et al. 1975, Lei et al. 1991). As previously described in the woman and cow (van Niekerk et al. 1975, Lei et al. 1991), also in the mare, large luteal cells present a light colour while small luteal cells are dark (Roberto da Costa et al. 2005). In contrast to other species, in the mare, small luteal cells are not of thecal origin (van Niekerk et al. 1975, Ginther 1992). Prior to ovulation, theca cells initiate their degenerative process and are replaced by fibroblasts (Ginther 1992). However, granulo-

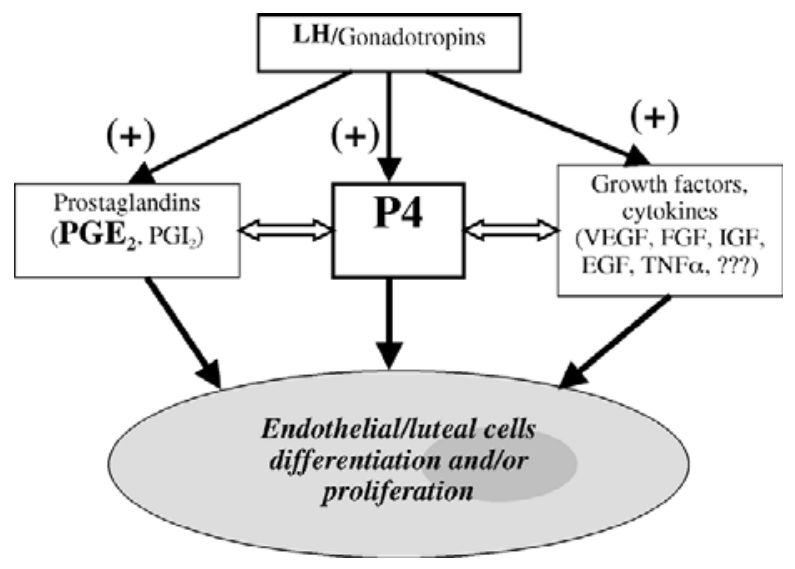

Fig 1 Hypothetical model of the regulation of equine $C L$ development (see text for the details).

Hypothetisches Modell zur Regulation der Entwicklung equiner Gelbkörper (detaillierte Beschreibung: vgl. Text).

sa cells undergo luteinization and secretory activity soon after (Ginther 1992). It is possible that small luteal cells are in fact precursors of large luteal cells (van Niekerk et al. 1975, Lei et al. 1991, Gregoraszczuk 1996).

The CL undergoes a fast physiologic growth, which is followed by a regression process characterized by changes and cell death (apoptosis) of both vascular and steroidogenic cells (Stouffer et al. 2001, Davis et al. 2003, Al-zi'abi et al. 2003, Ferreira-Dias et al. 2006a). Also in the mare, blood vessel growth and regression are coordinated with the development and regression of non-vascular tissue (steroidogenic cells included) (Ferreira-Dias et al. 2006a, Roberto da Costa et al. 2005). Throughout the luteinization process, during the equine $\mathrm{CL}$ formation, microvascularization is increased in early and mid-luteal phases (Ferreira-Dias et al. 2006a). This increment on angiogenesis is necessary for the formation and growth of the equine $\mathrm{CL}$, which is accompanied by an increase in P4 synthesis from a very early stage of the luteal structure (Ferreira-Dias and Mateus 2003, Ferreira-Dias et al. 2006a, Roberto da Costa et al. 2005) (Fig. 1.).

\section{Physiological mechanisms of regulation of CL formation}

The physiological processes of CL formation might be regulated by many different factors, still not completely understood (Fig. 1). In a recent study carried out in our laboratories, the effect of the cytokine tumor necrosis factor (TNF $\alpha$ ) and a nitric oxide (NO) donor, Spermine NONOate, on equine luteal explant production of angiogenic factor(s) was evaluated (Costa et al. 2006). It was observed that conditioned culture medium by early luteal tissue in the presence of TNF $\alpha$ or Spermine NONOate stimulated in vitro endothelial cell proliferation (Costa et al. 2006). Therefore, in the mare's early-luteal phase $\mathrm{CL}$, it appears that TNF $\alpha$ stimulates the production of angiogenic factor(s) (Costa et al. 2006) and also of P4 and prostaglandin (PGE2) E2 (unpublished data), necessary for both luteal angiogenesis and non-vascular development (Fig. 2). Furthermore, NO may also play a role on vascular growth of the equine $\mathrm{CL}$ during early-luteal development (Costa et al. 2006), when vascular development is more intense (Ferreira-Dias et al. 2006a) (Fig. 2).

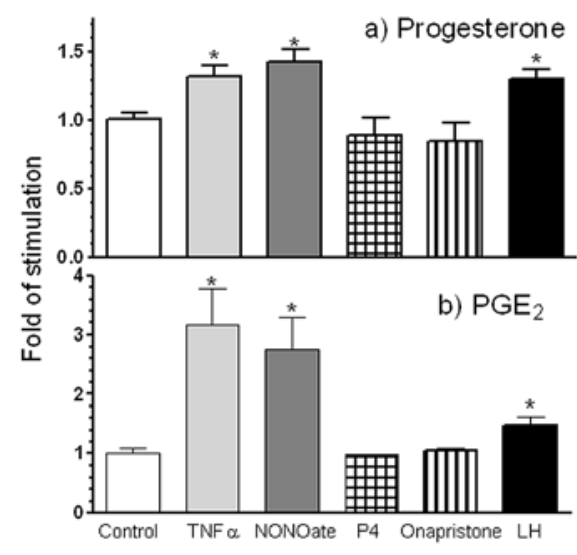

Fig 2 Effects of tumor necrosis factor-a (TNF $\alpha ; 10 \mathrm{ng} / \mathrm{ml}$ ), a donor of nitric oxide (NONOate; 10-5M), progesterone (10-5M), an antagonist of P4 (Onapristone; 10-5M) and LH (10 ng/ml) on progesterone (a) and prostaglandin E2 (b) secretion by equine corpora lutea from early luteal phase in vitro. For the details please see Ferreira-Dias et al. 2007, Costa et al. 2006 (adapted).

Auswirkung des Tumor Nekrose Faktor-a (TNFa; $10 \mathrm{ng} / \mathrm{ml})$, eines Stickoxid-Donors (NONOate; 10-5M), von Progesteron (10-5M), eines P4-Antagonisten (Onapristone; 10-5M) sowie von LH 10 $\mathrm{ng} / \mathrm{ml}$ ) auf die Progesteron- (a) und Prostaglandin E2- (b) Sekretion des equinen Gelbkörpers in der frühen Lutealphase in vitro. Eine detaillierte Beschreibung erfolgt in Ferreira-Dias et al. 2007 und Costa et al. 2006.

In the mare, even though the pulsatile pattern of P4 throughout the luteal phase is well established (Ginther 1992), the factors regulating P4 synthesis and its actions on the corpus luteum (CL) itself are not fully understood. The hormone P4 has been shown to act as a luteotrophin on the bovine $\mathrm{CL}$ mediated by oxytocin (OT) and/or prostaglandins (Skarzynski and Okuda 1999, Skarzynski et al. 2001, Kotwica et al. 2004), maintaining the synthesis of this steroid in the bovine ovary (Skarzynski and Okuda 1999, Skarzynski et al. 2001, Kotwica et al. 2004). Thus, as an autocrine factor, P4 exerts its action by a P4 receptor-dependent mechanism, suppres- 
sing the onset of apoptosis in the CL in several species (Rueda et al. 2000, Okuda et al. 2004). In the mare, plasma P4 increases simultaneously with a rise in both P4 receptor number, and large luteal cells PCNA expression and proliferation in the mid-luteal phase CL (Roberto da Costa et al. 2005). The presence of $\mathrm{P} 4$ receptors in the mare's CL suggests the importance of the autocrine regulation of the $\mathrm{CL}$ by ovarian steroids in this species (Fig. 1). Besides, large luteal cells might play an important role on most regulation or synthesis of P4 in equine luteal structures.

Progesterone, besides being the major hormone produced in the luteal tissue, also regulates prostaglandin synthesis by the bovine CL (Skarzynski and Okuda 1999, Skarzynski et al. 2001). The synthesis of prostaglandins in the newly formed CL may play important physiological roles such as cellular differentiation, intercellular communication and regulation of blood flow (Wiltbank and Ottobre 2003), that have not yet been clearly understood, especially in the mare. Therefore, in a recent study we examined whether P4 and its

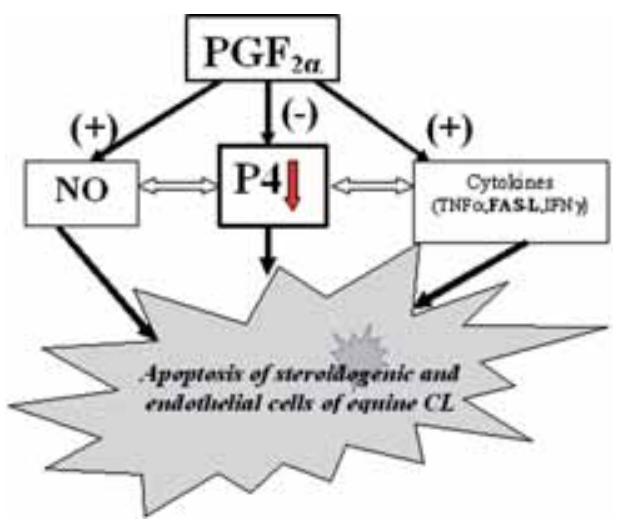

Fig 3 Hypothetical model of the structural and functional regression of equine $\mathrm{CL}$ (see text for the details).

Hypothetisches Modell zur strukturellen und funktionellen Regression des equinen Gelbkörpers (detaillierte Beschreibung: vgl. Text).

precursor pregnenolone may affect the synthesis of the luteotrophic PGE2 in the equine luteal tissue (Ferreira-Dias et al. 2006b). Mare's early and mid-luteal phases CL were able to release PGE2 in vitro (Fig 2), as previously reported for equine dispersed luteal cells (Watson and Sertich 1990). There was a significant increase in the production of this eicosanoid from early-luteal phase to mid- luteal phase CL. Although there was a tendency for an increase in PGE2 secretion in equine luteal tissues treated with pregnenolone, there were no significant differences in PGE2 release among all treatments (Ferreira-Dias et al. 2006b)(Fig. 2). These results may suggest a lack of P4 effect on prostaglandin secretion, in disagreement with what has been shown in bovine CL cells and tissue (Skarzynski and Okuda 1999). Another explanation might be the modulation of PG-converting enzymes activity (Watson et al. 1979, Beaver and Murdoch 1992, Asselin and Fortier 2000, Madore et al. 2003), the mechanism by which P4 could switch, in the equine $\mathrm{CL}$, from production of luteotrophic PGE2 to luteo- lytic PGF2 $\alpha$, or vice versa. However, further studies are needed to clarify this hypothesis.

\section{Luteolysis}

Loss of luteal function and/or luteal tissue involution

In the absence of pregnancy, the endocrine function the $\mathrm{CL}$ has prepared for, up to the mid-luteal phase, is no longer needed. The CL undergoes a process of functional and structural regression which mechanisms are far from being understood. The process of luteolysis is generally defined as loss of $\mathrm{CL}$ function and the subsequent involution of the luteal tissue. However, some authors consider functional and structural components of luteolysis as a continuum with loss of function, necessary for structural involution to proceed (Endo et al. 1993). In general, this dichotomy of loss of luteal function and/or luteal tissue involution is species specific. Whenever pregnancy fails to establish, luteolysis allows for the resumption of a new ovarian cycle. The CL drops its synthesis of P4, that is followed by structural regression of the $\mathrm{CL}$ (McCracken et al. 1999, Niswender et al. 2000, Okuda et al. 2004).

\section{Mechanisms of regulation of luteolysis}

In the mare, luteal tissue formation is followed by a decrease in plasma P4 concentrations, a fall in P4 receptors in the $\mathrm{CL}$, and vascular and non-vascular regression during tissue involution (Roberto da Costa et al. 2005, Ferreira-Dias et al. 2006a). Luteal vascular regression in the mare is coordinated with the regression of non-vascular tissue and might be regulated by many different factors (Ferreira-Dias et al. 2006a). Also in the mare, luteolysis depends on prostaglandin $F 2 \alpha$ (PGF2 $\alpha$ ) pulsatile release by the endometrium (Ginther 1992). Among many others, NO (Vega et al. 2000, Skarzynski et al. 2003), prostaglandin F2 $\alpha$ (McCracken et al. 1972,1999 ), and cytokines including TNF $\alpha$ (Friedman et al. 2000, Skarzynski et al. 2003) have been pointed out as luteolytic factors/mediators in several species (Fig. 3).

In a recent work, conditioned culture medium from mare's late-luteal phase CL treated with PGF2 $\alpha$ was able to inhibit in vitro endothelial cell proliferation (Ferreira-Dias et al. 2006a). Therefore, this hormone may also play a role on vascular regression of the $\mathrm{CL}$ during late-luteal phase in the mare (Ferreira-Dias et al. 2006a) (Fig.3). Besides this, luteal involution appears to be accompanied by a fall in P4 production (Ferreira-Dias et al. 2006a) (Fig.3).

In the mare, even though P4 might play an autocrine role on its synthesis in the early CL (Roberto da Costa et al. 2005), in the mid-luteal phase $\mathrm{CL}$, when angiogenesis is complete, long term exposure to progestagens appears to inhibit the angiogenic activity (Ferreira-Dias et al. 2006b). This apparent long-lasting inhibitory effects of P4 and its precursor pregnenolone on angiogenic factor(s) production by equine midluteal phase $\mathrm{CL}$, might be preparing the $\mathrm{CL}$ for functional and structural regression. This might be also a $\mathrm{NO}$ mediated process (Ferreira-Dias et al. 2006b)(Fig.3). Even though NO may play a role on vascular growth of the equine $\mathrm{CL}$ during earlyluteal development (Costa et al. 2006), it appears to have an 
opposite effect during mid-luteal phase CL (Ferreira-Dias et al. 2006b). Therefore, NO angiogenic and/or anti-angiogenic properties in the mare's CL need to be further investigated (Fig. 3).

\section{Apoptosis and luteolysis}

Apoptosis is involved in the process of structural involution of luteal tissue in many species (Rueda et al. 1997, Okuda et al. 2004, Skarzynski et al. 2005). In the mare, besides apoptosis, non-apoptotic changes might be also involved in luteolysis (Al-Zi 'abi et al. 2002). Since steroidogenic impairment precedes $C L$ structural involution in several species, the objective of a recent study was to evaluate the relationship between P4 secretion and caspase-3 activity. This was assessed by caspase- 3 expression and cleavage of its endogenous substrate poly ADP ribose polymerase (PARP), in equine cyclic luteal structures (Ferreira-Dias et al. 2007). Active caspase-3 expression was doubled in all luteal structures when compared to early luteal phase CL (Ferreira-Dias et al. 2007). This increase in caspase-3 activity was expressed in large luteal cells (Ferreira-Dias et al. 2007)(Fig. 4), where the presence of

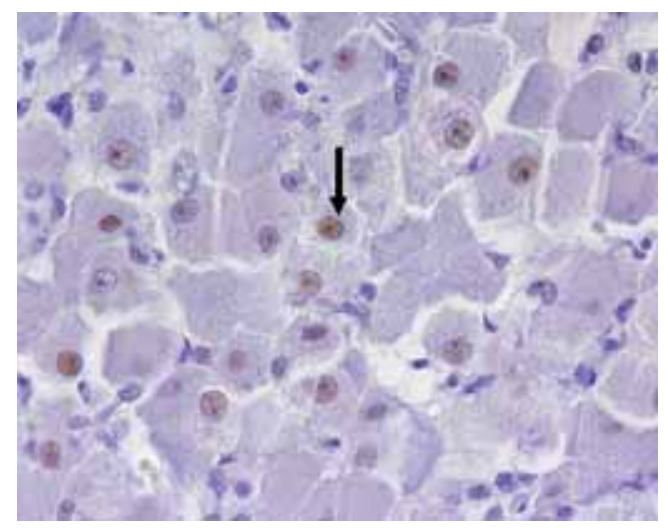

Fig. 4 Caspase-3 imunostaining of large luteal cells (black arrow) in the equine $\mathrm{CL}$. Photographed at mag=400x.

Immunhistologischer Nachweis der Caspase-3 in großen Luteinzellen (schwarzer Pfeil) des equinen Gelbkörpers (Gerätevergrößerung 400x).

P4 receptors has been reported (Roberto da Costa et al. 2005). Consistently, PARP was markedly degraded from early-luteal phase $\mathrm{CL}$ to corpora albicans. The decrease in P4 from mid to late-luteal phase $\mathrm{CL}$ was simultaneous with no further increases in apoptosis (Ferreira-Dias et al. 2007). This study suggests that caspase-3, might play an important role during luteal tissue involution in the mare, even though its relationship with P4 remains to be clarified.

\section{Conclusions}

Luteal formation in the equine ovary is a very complex physiological process that involves changes in microvascularization, steroidogenic tissue, and endocrine function, mainly on P4 production (Fig. 1). In the mare, it appears that the cytokine TNF $\alpha, N O$ and PGE2 are necessary for both luteal angiogenesis and non-vascular development. During the formation of early luteal structures in the equine ovary, P4 may play also an autocrine regulation of the CL (Fig. 1.). However, P4, cytoki- nes and NO might have opposite roles during luteal regression, that still remain to be clarified (Fig. 3). Cell proliferation reaches its maximum expression in the mid luteal phase, when apoptosis starts to prevail, leading to luteal regression. However, further studies are needed to elucidate the mechanisms of luteal formation and the relationship between the dichotomy of loss of function and/or luteal involution in the mare.

\section{Acknoledgments}

This work was supported by Grants "CIISA 45 Corpo Lúteo", from CIISA and "POCTI/CVT/39519/2001", from Fundação para a Ciência e Tecnologia (FCT), Portugal, and by the Special Grant of Polish Ministry of Sciences and Higher Education under Executive Programme of Scientific and Technological Co-operation between Republic of Poland and Portuguese Republic .

\section{References}

AL-zi'abi M. O., Watson E. D. and Fraser H. M. (2003) Angiogenesis and vascular endothelial growth factor expression in the equine corpus luteum. Reproduction 125, 259-270

Asselin E. and Fortier M. A. (2000) Detection and regulation of the messenger for a putative bovine endometrial 9-keto-prostaglandin E2 reductase: effector of oxytocin and interferon-t. Biol. Reprod. 62,125-131

Beaver C. J. and Murdoch W. J. (1992) Ovarian and uterine prostaglandin E2-9-ketoreductase activity in cyclic and pregnant ewes. Prostaglandins 44, 37-42

Broadley C., Menzies G. S., Bramley T. A. and Watson E. D. (1994) Isolation of cell populations from the mare corpus luteum: comparison of mechanical and collagenase dissociation. J. Reprod. Fertil. 102, 7-15

Costa A. S., Mateus L., Redmer D. A., Skarzynski D. J. and FerreiraDias $G$. (2006) Effects of TNF $\alpha$ and a nitric oxide donor on equine luteal production of factor(s) that stimulate endothelial cell proliferation. Reproduction in Domestic Animals 47, 361

Curry T. E. and Osteen K. G. (2001) Cyclic changes in the matrix metalloproteinase system in the ovary and uterus. Biol Reprod, 64, 1285-1296

Davis J. S., Rueda B. R. and Spanel-Borowski K. (2003) Microvascular endothelial cells of the corpus luteum. Reprod. Biol. Endocrinol. 1, 89

Endo T., Alen R. F., Wang T. and Behrman H. R. (1993) Coordinate induction and activation of metalloproteinase and ascorbic acid depletion in structural luteolysis. Endocrinology 133, 690-698

Ferreira-Dias G. and Mateus L. (2003) The equine cyclic corpus luteum: Microvascularization, luteal cells characterization and function. Pferdeheilkunde 19, 585-588

Ferreira-Dias G., Pinto Bravo P., Mateus L., Redmer D. A. and Medeiros J. A. (2006a) Microvascularization and angiogenic activity of equine corpora lutea throughout the estrous cycle. Domestic Animal Endocrinology 30, 247-259

Ferreira-Dias G., Costa A. S., Mateus L., Korzekwa A., Redmer D. A. and Skarzynski D. J. (2006b) Proliferative processes within equine corpus luteum may depend on paracrine actions. J. Physiology and Pharmacology 57 Supp. 8,139-151

Ferreira-Dias G., Mateus L., Costa A. S., Solá S., Ramalho R. M., Castro R. E. and Rodrigues C. M. P. (2007) Progesterone and caspase-3 activity in equine cyclic corpora lutea. Reproduction in Domestic Animals 42, 380-386

Friedman A., Weiss S., Levy N. and Meidan R. (2000) Role of tumour necrosis factor alpha and its type I receptor in luteal regression: induction of programmed cell death in bovine corpus luteum-derived endothelial cells. Biol. Reprod. 63,1905-1012 
Ginther O. J. (1992) Characteristics of ovulatory season. In: Reproductive Biology of the Mare - Basic and Applied Aspects. 2nd Ed), Equiservices, Cross Plains, Wisc. 171-232

Goldberg M., Moses M. A. and Tsang P. C. W. (1996) Identification of matrix metalloproteinases and metalloproteinases inhibitors in bovine corpora lutea and their variation during the estrous cycle. J. Anim Sci. 74, 849-857

Gregoraszczuk E. L. (1996) Large and small cells of the porcine corpus luteum: Different capacity to secrete estradiol and aromatize exogenous androgen during mid- and late luteal phase. Exp. Clin. Endocrinol. 104, 278-283

Juengel J. L. and Niswender G. D. (1999) Molecular regulation of luteal progesterone synthesis in domestic animals. J Reprod Fertil Suppl 54, 193-205

Kotwica J., Rekawiecki R. and Duras M. (2004) Stimulatory influence of progesterone on its own synthesis in bovine corpus luteum. Bull. Vet. Inst. Pulawy. 48, 139-145

Lawler D. F., Hopkins J. and Watson E. (1999) Immune cell populations in the equine corpus luteum throughout the oestrous cycle and early pregnancy: an immunohistochemical and flow cytometric study. J. Reprod. Fert. 117, 281-290

Lei Z. M., Chegini N. and Rao C. V. (1991) Quantitative cell composition of human and bovine corpora lutea from various reproductive states. Biol. Reprod. 44, 1148-1156

Madore E., Harvey N., Parent J., Chapdelaine P., Arosh J. A. and Fortier M. A. (2003) An aldose reductase with 20 a-hydroxysteroid dehydrogenase activity is most likely the enzyme responsible for the production of prostaglandin F2 $\alpha$ in the bovine endometrium. J. Biol. Chem. 278, 11205-11212

McCracken J. A., Carlson J. C., Glew M. E., Goding J. R., Baird D. T., Green K. and Samulesson B. (1972) Prostaglandin F2 identified as a luteolytic hormone in sheep. Nat. New Biol. 238, 129-134

McCracken J. A., Custer E. E. and Lamsa J. C. (1999) Luteolysis: a neuroendocrine-mediated event. Physiol. Ver. 79, 263-323

Murphy B. D. (2000) Models of luteinization - Minireview. Biol. Reprod. 63, 2-11

Niswender G. D, Juengel J. L., Silwa P. J., Rollyson M. K. and Mclntush E. W. (2000) Mechanisms controlling the function and life span of the corpus luteum. Physiol. Ver. 80, 1-29

Okuda K., Korzekwa A., Shibaya M., Murakami S., Nishimura R., Tsubouchi M., Woclawek-Potocka I. and Skarzynski D. (2004) Progesterone is a suppressor of apoptosis in bovine luteal cells. Biol. Reprod. 71, 2065-2071

Roberto da Costa R. P., Branco V., Pessa P., Robalo Silva J. and Ferreira-Dias G. (2005) Progesterone receptors and proliferating cell nuclear antigen expression in the equine luteal tissue. J. Reprod. Fertil. Develop. 17, 659-666

Rueda B. R., Tilly K. I., Botros J. W., Hansen T. R., Hoyer P. B. and TilIy J. L. (1997) Increased Bax and interleukin-1b-converting enzyme messenger ribonucleic acid levels coincide with apoptosis in the bovine corpus luteum during structural regression. Biol. Reprod. 56, 186-193
Rueda B. R., Hendry I. R., Hendry III W. J., Stormshak F., Slyden O. D. and Davis J. S. (2000) Decreased progesterone levels and progesterone receptor antagonist promote apoptotic cell death in bovine luteal cells. Biol. Reprod. 62, 269-276

Skarzynski D. J. and Okuda K. (1999) Sensitivity of bovine corpora lutea to prostaglandin $\mathrm{F} 2 \alpha$ is dependent on progesterone, oxytocin and prostaglandins. Biol. Reprod. 60, 1292-1298

Skarzynski D. J., Jaroszewski J. J. and Okuda K. (2001) Luteotropic mechanisms in the bovine corpus luteum: role of oxytocin, prostaglandin $F 2 \alpha$, progesterone and noradrenaline. J. Reprod. Develop. 47, 125-137

Skarzynski D. J., Jaroszewski J. J , Bah M. M., Deptula K. M., Barszczewska B., Gawronska B. and Hansel W. (2003) Administration of a nitric oxide synthase inhibitor counteracts prostaglandin F2 $\alpha$ induced luteolysis in cattle. Biol. Reprod. 68, 1674-1681

Skarzynski D., Jaroszewski J. J. and Okuda K. (2005) Role of tumor necrosis factor-a and nitric oxide in luteolysis in cattle. Dom. Animal. Endocrinol. 29, 340-346

Stouffer R. L., Martinez-Chequer J. C., Molsknee T. A., Xu F. and Hazzard T. M. (2001) Regulation and action of angiogenic factors in primate ovary. Arch. Med. Res. 32, 567-575

Tamanini C. and De Ambrogi M. (2004) Angiogenesis in developing follicle and corpus luteum. Reprod. Dom. Anim. 39, 206-216

Van Niekerk C. H., Morgenthal J. C. and Gerneke W. H. (1975) Relationship between the morphology of progesterone production by corpus of the mare. J. Reprod. Fert. Suppl. 23, 171-175

Vega M., Urrutia L., Iniguez G., Gabler F., Devoto L. and Johnson M. C. (2000) Nitric oxide induces apoptosis in the human corpus luteum in vitro. Mol. Hum. Reprod. 6, 681-687

Watson J., Shepherd T. S. and Dodson K. S. (1979) Prostaglandin E29-ketoreductase in ovarian tissues. J. Reprod. Fertil. 57, 489-496

Watson E. D. and Sertich P. L. (1990) Secretion of prostaglandins and progesterone by cells from corpora lutea of mares. J. Reprod. Fertil. 88, 223-229

Wiltbank M. C. and Ottobre J. S. (2003) Regulation of intraluteal production of prostaglandins. Reprod. Biol. Endocrin. 1, 91-112

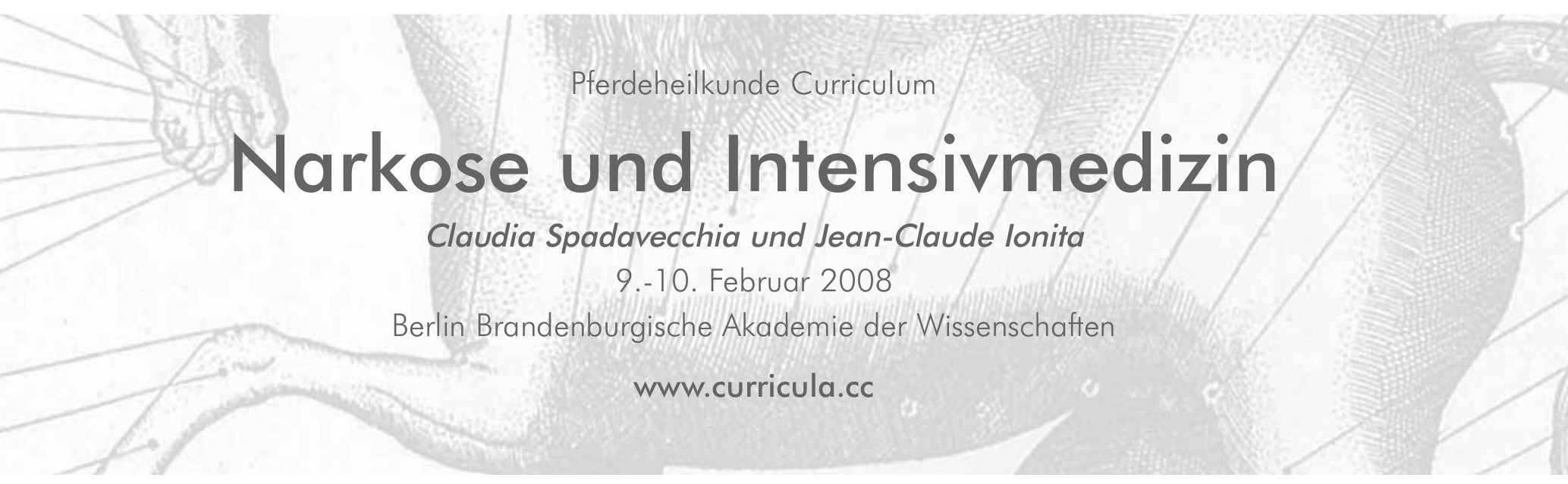

